\title{
Embracing the lash
}

\section{Pain and ritual as spiritual tools}

\section{Introduction}

'When the whip is raised, when leather, scourge, and cane strike against covered or naked flesh, we stand before a stage-a stage on which ritual unfolds' (Largier 2007: 13). This chapter explores the use of scourging in Wicca, where the unfolding of ritual takes place within a larger ritual context, potentially magnifying the efficacy of pain as a nexus of transformation and transcendence, in which flagellation 'is not merely a type of beating or a manner of generating pain. Instead, it evokes a complex, multi-layered, imaginary horizon that encompasses religious, erotic, and legal frames of reference.' (Largier 2007: 14.)

Whilst the use of flagellation for the purposes of purification, punishment or redemptive salvific activity has long been accepted in Christianity, its use in newly emergent religions such as Wicca, where the religious use of pain cannot be sidelined as an historical aberration but must instead be understood within the context of (post)modern spirituality, has elicited little debate. Whilst purification and, to a far lesser extent, punishment still have their place, in Wicca submission to pain must also be explored in terms of initiatory ordeal, as well as an opportunity for transcendence and as arousal, sensation, and energy generation. However, voluntary submission to the infliction of pain, especially in order to enable religious/spiritual experience, tends to be regarded as anathema and as such, remains largely hidden, concealed behind a veil of categorisations of sexuality and psychopathology developed since Krafft-Ebing in 1886. Whilst acknowledging that BDSM remains taboo amongst most practitioners of Wicca, this 60 year old religion contains within its practices elements of techniques often associated with BDSM, techniques which, though having an established history in the world's religions, are now being pioneered by a small cohort of priests and priestesses within the ritual framework of a twentieth/twenty-first century religion. 
Techniques associated with BDSM in the public imagination-specifically, blood restriction through binding and bondage, and flogging/scourgingtend to be ignored, sidelined, dismissed, and whitewashed, both by Wiccan practitioners and by academic studies of Wicca, rather than being explored as mechanisms by which boundaries might be transgressed through the infliction of pain, exercised on the body, eliciting religious experience from skin and flesh. Aidan Kelly (1991), for instance, makes passing reference to sexual excitement induced through scourging in Wiccan rites, whilst Ronald Hutton (1999) claims asthma and a genuine belief that bondage and scourging were idiosyncratic ways of attaining an ecstatic trance as reasons for the inclusion of scourging in Wiccan ritual contexts. ${ }^{1}$ Neither makes any links to the long history of religious flagellation, to BDSM, or to pain. ${ }^{2}$ I do not intend here to present an account of the history of flagellation, about which much has been written. ${ }^{3}$ Instead, I want to concentrate on those elements now more or less stripped of their association with medieval Christianity, and more commonly framed within the context/s of BDSM.

\section{Wicca: a brief introduction}

Wicca emerged in the 1940s, in an area of England known as the New Forest. Initially devised by a retired civil servant called Gerald Gardner, it drew heavily on Freemasonry, the occult societies of the late nineteenth-early twentieth centuries, the work of Aleister Crowley, and a panoply of novels, poetry and

$1 \quad$ Kelly claims that, 'the rites can be boiled down to a set of practices designed to induce sexual excitement by scourging, and that this was Gardner's distinctive personal contribution to, and main emotional investment in [Wicca]' (Hutton 1999: 235), though it seems that there were more complex issues at work, including Gardner's asthma, which disabled him from other more energetic mechanisms for entering trance states, and a genuine belief that bondage and scourging were idiosyncratic ways of attaining an ecstatic trance. As Hutton discerns (ibid.), Gardner's novels are not works of flagellant fiction and his scrapbooks, though containing some erotic images of 'pretty, nude young women', are not concerned with binding or flagellation. He concludes, ' $[\mathrm{t}$ ] his is not the profile of a straightforward flagellant' (p. 235). I began to explore this in a paper presented at the conference 'Dangerous Sex: Contesting the Spaces of Theology and Sexuality', University of Glasgow, 2002. My argument was that, whilst there is a common conceptual ground between Wicca and BDSM, the overlaps between the two remain unexplored, both by academics and by Wiccan practitioners themselves. This is still the case, and the continued 'whitewashing' of Wicca has been ongoing since I wrote that paper. See Pearson 2005. See, for example, Largier 2007 and Roudinesco 2009. 
academic work on European witchcraft and folklore. It styles itself as an initiatory mystery religion, after the mystery cults of the classical ancient world, operating for the few rather than for the many, and with attendant ideas of priesthood and of secrecy. This latter is not concerned with content per seafter all, one can download a number of Books of Shadows from the internet, and purchase a variety of 'how-to' books from the shelves of any bookshop. Rather, secrecy is concerned with the centrality of ritual praxis to Wicca, an understanding of which prioritises the essential role of experience over book learning, of experiential knowledge as a means of learning those things that cannot, in a sense, be taught. Such things include the use of various means of entering into alternative states of consciousness.

Contained within the materials Gardner brought together were a number of techniques typically believed to facilitate trance states and magical work, both in terms of specific spells and with regard to the alchemical transformation of the self. These eight techniques, which can be practised independently of each other, or in combination-drugs and ritual, trance and dance, sex and scourging, for example-are as follows: meditation; trance; dance; rites and spells; drugs, wine etc; the Great Rite (ritualised sex, usually practised by a couple); blood control/binding; and scourging. It is on scourging and, to a lesser extent, binding that I wish to concentrate.

\section{The scourge in Wicca}

The scourge is generally understood in Gardnerian and Alexandrian Wicca as one of eight magical weapons and, as we have seen, its use is listed as one of the eight paths of magic. Yet, unlike the other magical weapons, it has no provenance/pedigree in older magical systems such as that contained within The Key of Solomon or in the occult societies of the late nineteenth century 4 -although it does, of course, have a high profile in the cultural history of that era. As an instrument used for the purposes of flagellation, the scourge-along with rods, canes, switches, and whips-is, of course, associated with what the French termed 'le vice Anglais', the penchant for flagellation supposedly being inherent in the English, inculcated in English public

Although it could be argued that the imagery of the flail associated with the Egyptian god Osiris and used extensively by the Hermetic Order of the Golden Dawn evokes similar ideas to the Wiccan scourge, the crook (wand) and flail (scourge) being also equated with the pillars of Mercy and Severity respectively in the kabbalistic system central to the Order. 
schools (specifically Eton) and practised, at least by the higher echelons of society, in private 'spanking' clubs. Gardner, however, never went to school at all; and yet he is widely believed to have introduced the scourge as the eighth magical weapon in his witchcraft religion. ${ }^{5}$ Why? And whence did the idea of the scourge as an instrument of magic in modern witchcraft arise?

As noted earlier, the practice of scourging and binding, according to Aidan Kelly, came from Gerald Gardner's own sexual predilections, though Hutton argues that this is not the case. One of Gardner's initiates, Olive Greene, claimed that, for Gardner, hard strokes of the scourge were necessary. She reports that:

[she] was only flicked lightly, but Gerald liked the strokes hard and strong. I was very nervous of administering such harsh punishment. Having had no experience of such things I started by tentatively flicking the scourge across him, believing it to be a purely symbolic action. But Gerald became very excited. First I had to warrick and warlock him, and he liked to be very tightly tied, so that the cords cut into his flesh. He then knelt at my feet, with his head bowed down and resting on the altar table. He was pathetically thin and emaciated. I felt one hard lash of the scourge and he would snap in two. But all the time he kept crying; 'Harder, dear, harder. I can't feel it at all. You must make the blood course.' He swayed as he knelt, and each time he felt the scourge, his head knocked the table and rattled all the tools on the altar. He kept multiplying the number of strokes to make it more and more. He said the reason for this was magical. (Heselton nd: np.)

There is, however, no corroborating evidence for this, and Greene's testimony is undermined by her later collaboration with Charles Cardell in the Rex Nemorensis scandal; whether she was sent by him to infiltrate Gardner's coven, or whether she simply became disillusioned after her initiation and told Cardell everything, her reports cannot be taken at face-value. The evidence for Gardner's taste for hard flogging therefore remains inconclusive, although it is a commonly held 'truth' among Gardnerian covens. ${ }^{6}$ In fact,

Philip Heselton (2003: 270-1) disputes this, claiming that a scourge was already in use and included among the magical weapons in the New Forest coven into which Gardner claimed he was initiated in 1939.

6 An early Gardnerian initiate, Fred Lamond, claims that, '[prior to 1958] binding and scourging was the only method we used for raising power, because it was the only one that worked for Gerald. The coven member who knew the person we were 
Gardner appears to have regarded scourging as a particularly effective means of inducing trance and/or raising magical power. In The Witches' Way, Janet and Stewart Farrar cite a magical manuscript reputed to be Gardner's, in which Gardner argues that,

The simplest way [of raising power] is by dancing and singing monotonous chants, slowly at first and gradually quickening the tempo until giddiness ensues. Then the calls may be used, or even wild and meaningless shrieking produces power. But this method inflames the mind and renders it difficult to control the power, though control may be gained through practice. The scourge is a far better way, for it stimulates and excites both body and soul, yet one easily retains control. (Farrar \& Farrar 1985: 53.)

What is certain is that binding and blindfolding are accepted as practices with a long pedigree in Masonic circles, and Gardner certainly drew heavily on his experience as a Freemason, particularly for his initiation rites (see Bogdan 2007). Scourging, however, more commonly tends to be associated with perversion, BDSM and with Christianity, and reactions vary. As Paul Huson noted in 1970:

many traditional-minded witches feel that [scourging] ... though peculiar to certain aspects of later Roman versions of the Greek mysteries, seems to be more bound up with English 'public school' and 'spankers' club' traditions than any inherent in the craft itself. To be beaten, whether symbolically or in actuality, does not by any means arouse in everyone the same feelings of glowing inner cleanliness or spiritual tone-up that it apparently did for a Nordic warrior, cloistered medieval monk, English public school boy, or sky-clad witch. (Huson 1970: 214-15.)

However, as Huson indicates here, although BDSM tends to draw on Christian practices of flagellation and associated imagery, Wicca aims to draw on preChristian notions and practices, including that of flagellation. Gardner cer-

working for best knelt in the middle of the circle and was scourged by his or her partner while the rest of the coven just stood around them in a circle and contributed their power. ... In the spring of 1958, after Gerald had left us to spend the summer on the Isle of Man, we decided that the B\&S method of raising power was too damn boring. So we switched to the circle dance method of raising power. . . (Heselton nd: 20-1.) 


\section{JO PEARSON}

tainly seems to have been convinced of the appropriateness of scourging in the ancient mystery cults, from which he believed Wicca primarily derived. In his first non-fictional work on Wicca, Witchcraft Today, published in 1954, he discusses the frescoes from the Villa of the Mysteries in Pompeii. He quotes a description of the frescoes from Vittorio Macchioro's The Villa of the Mysteries in Pompeii (1920). Of particular interest is the panel which Macchioro describes as follows:

Talatē7 stays her gesture with her hand and lifts the rod whilst the maiden kneels bewildered and terrified with her face well-nigh hidden in the lap of a compassionate priestess, to endure the ritual flagellation which replaces and symbolises death. Psychically she does not die, but she passes symbolically through death and dies mystically as the stigmatists die crucified in Christ. (Macchioro 1954: 101.) ${ }^{8}$

In his use of this description, Gardner stresses the symbolic death that initiates of the Mysteries were required to undergo, and the role of flagellation in this process - the necessity of pain for spiritual rebirth. It is a general theme of the later Roman versions of the Greek Mystery cults, and can also be seen in festivals such as the Lupercalia, during which women held out their hands to the whips held by men running through the streets, the touch of said whips being the awakener of desire and fertility. This idea of spiritual 'awakening' through the symbolic death of initiation is a standard part of Wicca, and since all births contain pain, in Gardnerian and Alexandrian Wicca in the UK scourging almost universally forms an important part of all three rituals of initiation (1st, 2nd and $3 \mathrm{rd}$ degree). The initiate is bound, blindfold and naked, purified with scourging, and then consecrated. 9 In many covens, scourging is practised only as part of initiation rituals, during which a prescribed number of strokes are administered. According to Hutton, 'the cords are used to apply a gentle restriction of the blood circulation to produce dizziness, and the scourge is applied very lightly and steadily to induce a rhythmical tingling

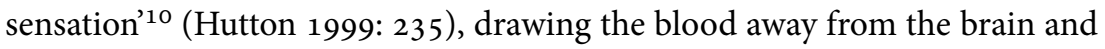
into the body, thus enabling the person being scourged to enter a more 'pure'

7 Daughter of Dionysus.

8 Doreen Valiente describes it as 'an ordeal which the neophyte had to pass, and also perhaps as a means of purification before a person was admitted to the Mysteries' (1994: 139).

9 See Vivianne Crowley 1990: 47, for an account of her initiation.

10 I.e. he stresses that this is not about pain. 
state of consciousness. Likewise, Vivianne Crowley refers to this as a 'symbolic' activity, which,

is not designed to cause pain. This is not because of Western squeamishness. Most people are prepared to suffer in order to be worthy of initiation. [But] today... physical endurance is a minor part of our lives and the gifts of initiation are not won by undergoing a small amount of physical discomfort. It is an effort of the mind, soul and spirit which is required to achieve the goal of initiation-higher consciousness.

(Crowley 1996: 116.)

For the vast majority of Wiccans, initiations will be their only experience of a practice that could be interpreted as BDSM, their only voluntary submission to the potential infliction of pain. In some cases, even the potential for experience of pain is removed, for the scourge itself may consist of pieces of cotton thread or ribbons rather than anything more substantial. In cases where infliction of pain is clearly not the aim, to the extent that it would be well nigh impossible to cause even 'a small amount of physical discomfort' with the instrument used, Crowley's 'effort of mind, soul and spirit' becomes the primary means through which altered-, higher- or trance states of conscious are achieved. Thus, the body may be a strong physical ritual presence, being a naked, bound receiver of light strokes from the scourge (as Hutton suggests), but its power to effect transformation is thereby limited, and its ambiguous position in a religion that claims to dissolve the traditional mind-body dualisms is underlined. 'The primary subject [of] the skin, with its keen sense of touch and feeling, its sensitivity to excitement' (Largier 2007: 22) is subjected only to low-level arousal through which a trance state would seem impossible to achieve. And so the body appears to be under-utilised as a vehicle within which one might be 'transported' - to use William James's term-through pain, contact, rhythm, sound, as practitioners play with taboos in a tantalising rather than liberating manner. Thus, whilst accepting Carl B. Holmberg's argument that '[a]pproaching the edge of taboo intensifies feelings and even a sense of the sacred ... [arousing] not just physically, but spiritually' (Holmberg 1998: 93), and Niklaus Largier's observation that 'the whip and the rod...embody the unity of physical and psychical arousal' (2007: 315), actually going beyond Georges Bataille's (1986) fascination of transgression, pushing oneself over the edge, 'taking on transgression, facing it, and incorporating it into... performance of self' (Holmberg 1998: 96), is not most Wiccans' response to the praxis of flagellation. 
In fact, we can identify three main responses, or interpretative strategies to scourging and binding: rejection, acceptance, and enthusiastic advocation. At one end of the spectrum are those for whom the use of scourging and blood control through bondage, are inappropriate, dangerous, and have no place in Wiccan ritual. Such people, as individuals or covens, have removed the scourge from their altars, do not use it even at initiations, and do not practice binding. This is most common amongst practitioners of feminist witchcraft, many of whom see the scourge as a symbol of (patriarchal) oppression, of sexual domination, of BDSM practices, and of 'power-over', although I have also come across one or two instances of this response among Gardnerian and Alexandrian witches. The use of the scourge seems to be considered 'a perverse transgression of the taboos of bondage, pain, humiliation, and dominance' (Holmberg 1998: 96).

By far the most common position is that of acceptance. The scourge remains one of the eight magical weapons, is placed on the altar, and is used at initiations and at other times. It is understood as a symbol of discipline, ${ }^{11}$ 'sign of power and dominance', and the ritual agent of 'suffering and purification' used to administer initiatory ordeals (Hutton 1999: 229). Whilst nearly all Wiccans submit to the scourge as part of the ordeal of initiation, others use it far more often, and for a variety of purposes: aside from initiations, many Gardnerian covens use scourging as a means of purification before each and every rite, for trancework and divination (especially scrying), spellcraft, and to discipline misdemeanours in ritual. ${ }^{12}$

But this is still not-necessarily-embracing the lash, still not using pain. We thus come to a third position in relation to the scourge, a position at the opposite end of the spectrum to those who reject the scourge, similarly occupied by very few Gardnerian and Alexandrian Wiccans. These are the enthusiastic advocates, Wiccans perhaps with an interest in BDSM who make greater use of bondage and flagellation, and experiment with pain, drawing such techniques into the rituals of Wicca and regarding them as an inherent part of Wiccan ritual. For them, the abstract or symbolic appreciation

11 The instruments of flagellation were, of course, historically known as the disciplina. As such, it is a symbol of discipline-of the self as well as others, and more importantly the former. As Vivianne Crowley states, the scourge is a tool which it is important we make and consecrate ourselves; for it is a symbol of the self-discipline that is necessary to follow an initiatory path. The teaching given with the scourge in the first degree was that the initiate should be willing to suffer to learn. (Crowley 1996: 199.) This is something I have seen taken very seriously, but most often in light-hearted fashion. 
of scourge and cords or, even worse, their removal from the altar, signifies a 'white-washing' of Wicca. These are the practitioners who do embrace the lash, who do utilise pain.

\section{Embracing the lash}

I want to reiterate here that Wiccans at this end of the spectrum are extremely few and far between-I am talking about a handful of people within Gardnerian and Alexandrian Wicca, although we might note that many people in the wider Pagan community experiment with mixing BDSM techniques and religious ritual (see Kaldera 2006). But I have never been an advocate of the idea that large numbers are required in order for a study to be viable. If 'one of the major "tasks" of theories of deviance is to protect the legitimacy of theories of normality' (Simon 1996: 116), even in communities such as Wicca that are already regarded as transgressive, that already 'agree to translate into strange acts the inadmissable tendencies that haunt us and that we repress' (Roudinesco 2009: 5), then the apparent extremities of those who push the boundaries within a transgressive community perform a function in challenging the perversity of a religion that seeks simultaneously to both unleash and tame its dark side.

In 'Masochism as Escape from the Self', Roy Baumeister suggests that non-clinical masochists are 'normal' in every aspect of their lives other than the sexual, and tend to be high achievers, well-educated, and in positions of responsibility-in fact, they belong to exactly the same social profiling as most Wiccans, ${ }^{13}$ and members of NRMS in general. Yet, as I have indicated, very few Wiccans practice BDSM techniques or combine them with Wicca. Baumeister argues that masochism is comparable to intoxication, physical exercise, and meditation in its ability to facilitate removal from a high level of self-awareness, the powerful intensity of its sexual connotations being the only real difference. Furthermore, he suggests that the resulting low-level state of awareness brought about through the infliction of pain, the relinquishing of control, and subjecting oneself to humiliation (which he regards as the three principal tropes of masochism), enable transformation of the self, temporal and spatial focus on the immediacy of the present, and a concomitant narrowing of awareness to the physicality of the body-even more specifically, to that part of the body that is being subjected to the infliction of pain. 
Yet we must go further that this if we are to understand the use of binding and scourging and pain in Wiccan ritual. Pain, Elaine Scarry claims, 'obliterate[s] psychological content' and 'banish[es] abstract meanings and symbols from awareness' (cited in Baumeister 1988: 38); but this is to miss the importance of the explosion of pain as an intense sensation in the body itself. Pain generates a chemical response, an endorphin rush that produces a trance state through the physical body. It may also obliterate connection between the mind/spirit and the body, through the body, enabling the witch to move into a space between 'the experience of the body and the domination of the [rational] mind' (Cosgrove 1999: 433), a space in which the imagination, the image, is unfettered and released. The 'simulation of boundlessness' through binding evokes 'a place where freedom seeks to reach beyond the dichotomy of choice and compulsion' (Largier 2007: 22), where the unfettered 'imagination - whether through the experience of [the gods] or the drunkenness of the senses' (p. 30) - attained through the infliction of pain via scourging, enables an intensification of experience through a radical affirmation of the body.

This intense sensual-imaginative perception was exiled by the discourse of 'sexuality' begun in the late nineteenth century and continuing ever since, such that "imagination is subordinated to a "natural sexuality" ratified by reason, a "natural sexuality" that possesses its finality in the hetero-normative performance of the "sexual act"' (Largier 2007: 446). Embracing the lash thus undermines the ambiguity of arousal that rejects the dominance of the 'sexual' or 'sexuality' over the body, and instead allows the body to become a site of boundlessness which opens up inner possibilities of experience rather than a container that, in seeking satisfaction, closes down the interaction between mind and body through the finality of orgasm. In suspending the end of arousal, in opening up to the 'endless multiplication of arousal' (Largier 2007: 447), the rhythm of flagellation and the intense sensory experience of pain has the potential to open the gateway to the affinity with representation and image that forms an essential part of magical ability.

In speaking of 'magical ability', I am referring not only to traditions of spellcraft commonly associated with witchcraft in the popular imagination, but to the alchemical idea of the 'great work', the very transmutation of the Self, central to Wicca as an initiatory system. This is the 'greater magic', little understood by those who look for magical powers evinced by spells, talismans and potions, and to some would seem to relate more to the mystical, although in Wicca the magical and the mystical are not regarded as opposites, any more than magic is regarded as something that is separate, or prior to, re- 
ligion; indeed, the two are seen as intrinsic to each other. This 'greater magic', practised on the self, and the experience of the mystical that forms part of it, may be intensified through techniques that allow for an immediacy of effect on the psyche, including those that operate through sensation applied to the body, including voluntary submission to the infliction of pain.

Those who seek pain might be more easily identified with motifs of religiosity such as the flagellant or the martyr. Yet hyper stimulation through scourging in order to raise, manipulate and release magical energy requires the help of a fellow priest or priestess willing to wield the scourge, for it is not so easy-though also not impossible-for the Wiccan to inflict the scourge on themselves. In the dynamic between scourge and scourged, the distinction between self and other breaks down, the instrument used being perceived as an extension of the hand that wields it, the contact with the skin facilitating arousal in both parties through tactile and visual perception. As Largier notes, such tactile and visual perception is focused on specific regions of the body,

yielding an intensity that increases with every blow. The increased reddening of the skin becomes a stimulus in its own right, one that evokes urgency and concentration even in purely visual terms. All of these blows, moments of contact with the skin, and rhythmic sounds leads to a state of arousal not unlike a trance; indeed, it often takes precisely this form.

(Largier 2007: 23.)

Both parties serve each other, in a disruption of traditional understandings of the dynamics of power in an economy of normalised sexuality, in which the refusal to seek closure facilitates an exploration beyond demarcated boundaries, in the margins between the mind and the body.

\section{Conclusion}

Wicca plays on these margins to a far higher degree than most other religious traditions; that it has room for transgression within its own frame is a reflection of the way in which it encourages individual exploration into ways of being, and largely refrains from judging others over the choices they make to facilitate their spiritual growth. Those who reject or accept the scourge are not denying the importance of the body and its centrality to Wicca; it is simply that those who embrace the lash choose to use the body as a specific tool in 
an additional way, a way which utilises pain and seeks to master it. Thus, if what worked for Gardner was flagellation (whether because of his asthma, his own sexual leanings, or for any other reason), that's fine. Equally, if what works is dance, meditation, or drugs, that is also fine. So long as no harm is done to oneself or others, Wicca has no rules governing choice of magical technique. And flagellation, let us be quite clear, is about inflicting pain, not harm or injury; its use must be consensual, otherwise it is as abusive as any act of violence perpetrated on the body of another.

The use of the scourge in Wicca represents a religious, spiritual, and magical use of the body that introduces pain as arousal and transcendence, rather than as mortification, asceticism, or punishment of the body. The body is elevated to a site of spiritual experience encountered through intense ritual praxis within a wider ritual context. The use of the physical in order to reach 'beyond' the body in fact carries, or transports the body into a different relationship with mind, spirit, soul, one in which all are combined or modulated in the boundless realms of the imagination, beyond the constructed limits of what constitutes physicality - and beyond what is normally understood to constitute religion. The traces that the scourge leaves behind on the body are marks both of an encounter with the infinite, and of an experience of selftransformation.

\section{Acknowledgements}

I am grateful to Dr Conrad Harriss for furnishing me with the title for this paper and for many helpful discussions; and to Philip Heselton for kindly making available to me a draft manuscript of his forthcoming biography of Gerald Gardner.

\section{Bibliography}

\section{Bataille, Georges}

1986 Erotism: Death and Sensuality. Trans. Mary Dalwood. San Francisco: City Lights Books.

\section{Baumeister, Roy F.}

1988 Masochism as Escape from Self. The Journal of Sex Research 25 (1): 28-59.

\section{Bogdan, Henrik}

2007 Western Esotericism and Rituals of Initiation. New York: SUNY Press.

\section{Cosgrove, Peter}

1999 Edmund Burke, Gilles Deleuze, and the Subversive Masochism of the Image. ELH 66 (2): 405-37. 


\section{Crowley, Vivianne}

1990 The Initiation. In: Prudence Jones \& Caitlin Matthews (eds), Voices from the Circle: The Heritage of Western Paganism; pp. 65-82. London: Aquarian Press.

1996 Wicca: The Old Religion in the New Millennium. London: Thorsons.

\section{Farrar, Janet \& Stewart Farrar}

1985 The Witches' Way. London: Robert Hale.

\section{Heselton, Philip}

nd Father of the Witches. London: Thoth Publications (forthcoming).

2003 Gerald Gardner and the Cauldron of Inspiration: An Investigation into the Sources of Gardnerian Witchcraft. Milverton: Capall Bann.

\section{Holmberg, Carl B.}

1998 Sexualities in Popular Culture. London: Sage.

\section{Huson, Paul}

1970 Mastering Witchcraft: A Practical Guide for Witchces. Warlocks and Covens, London: Corgi.

\section{Hutton, Ronald}

1999 The Triumph of the Moon: A History of Modern Pagan Witchcraft. Oxford: Oxford University Press.

\section{Kaldera, Raven}

2006 Dark Moon Rising: Pagan BDSM and the Ordeal Path. Hubbardston, MA: Asphodel Press.

\section{Kelly, Aidan}

1991 Crafting the Art of Magic Book 1: A History of Modern Witchcraft, 1939-1964. St Paul, MN: Llewellyn Publications.

\section{Largier, Niklaus}

2007 In Praise of the Whip: A Cultural History of Arousal. New York: Zone Books. Pearson, Joanne

2003 "Witchcraft will not soon vanish from this earth": Wicca in the $21^{\text {st }}$ Century. In: Linda Woodhead, Grace Davies \& Paul Heelas (eds), Predicting Religion: Christian, Secular, and Alternative Futures; pp. 170-82. Aldershot: Ashgate.

2005 Inappropriate Sexuality? Sex Magic, S/M and Wicca (or Whipping Harry Potter's Arse!). Theology and Sexuality 11 (2): 31-42.

2007 Wicca and the Christian Heritage: Ritual, Sex and Magic. London: Routledge.

\section{Roudinesco, Élisabeth}

2009 Our Dark Side: A History of Perversion. Cambridge: Polity Press.

\section{Simon, William}

1996 Postmodern Sexualities. London: Routledge.

\section{Valiente, Doreen}

1994 An ABC of Witchcraft Past and Present. London: Robert Hale. (First published in 1973.) 